\title{
Vitamin D status in apparently healthy medication-free Slovaks: Association to blood pressure, body mass index, self-reported smoking status and physical activity
}

\author{
Sebekova $\mathrm{K}^{1}$, Krivosikova $\mathrm{Z}^{2}$, Gajdos $\mathrm{M}^{2}$, Podracka $\mathrm{L}^{3,4}$ \\ Institute of Molecular BioMedicine, Medical Faculty, Comenius University, Bratislava, Slovakia. \\ kata.sebekova@gmail.com
}

\begin{abstract}
BACKGROUND: Vitamin D plays a role in protecting against chronic degenerative diseases. Slovak adults present one of the highest cardiovascular mortality rates among $27 \mathrm{EU}$ countries.

OBJECTIVES: We asked whether the $25(\mathrm{OH}) \mathrm{D}_{3}$ status in apparently healthy medication-free Slovaks deteriorates upon ageing, and in the presence of cardiometabolic risk factors.

METHODS: We studied the impact of blood pressure, overweight/obesity, smoking, and physical activity on $25(\mathrm{OH}) \mathrm{D}_{3}$ levels determined using RIA method in 578 (5-81 years old) subjects.

RESULTS: The average level of $25(\mathrm{OH}) \mathrm{D}_{3}$ was $36 \pm 17 \mathrm{ng} / \mathrm{ml}$. A proportion of $15 \%$ of participants were $25(\mathrm{OH})$ $\mathrm{D}_{3}$-deficient $(\leq 20 \mathrm{ng} / \mathrm{ml}), 26 \%$ presented insufficient $(20$-to- $30 \mathrm{ng} / \mathrm{ml})$, and $59 \%$ satisfactory $(>30 \mathrm{ng} / \mathrm{ml})$ levels. Neither mean $25(\mathrm{OH}) \mathrm{D}_{3}$ levels, nor the prevalence of hypovitaminosis $\mathrm{D}$ showed age dependence. Physically active normotensive non-smokers presented the highest $(41 \pm 19 \mathrm{ng} / \mathrm{ml})$, and their smoking counterparts with elevated BP the lowest $25(\mathrm{OH}) \mathrm{D}_{3}$ levels $(30 \pm 12 \mathrm{ng} / \mathrm{ml})$.

CONCLUSION: In apparently healthy medication-free Slovaks the prevalence of hypovitaminosis D is high. Vita$\min \mathrm{D}$ status does not deteriorate in course of healthy ageing. Physical activity, normotension, and non-smoking status are associated with favorable vitamin $D$ status while low $25(\mathrm{OH}) \mathrm{D}_{3}$ levels are associated with multiple cardiometabolic risk factors. Further studies in subjects at high cardiovascular risk are needed to elucidate the potential association of hypovitaminosis D with high cardiovascular mortality in Slovak adults (Tab. 1, Fig. 4, Ref. 42). Text in PDF www.elis.sk.

KEY WORDS: vitamin D, blood pressure, smoking, physical activity, body mass index.
\end{abstract}

\section{Introduction}

Vitamin D is a fat-soluble steroid, formed in the dermis from 7-dehydrocholesterol via ultraviolet irradiation. Provitamin $\mathrm{D}_{3}$ quickly undergoes photochemical and thermal rearrangements to form a stable vitamin $\mathrm{D}_{3}$. After binding to vitamin D-binding protein (DBP), it enters circulation and is hydroxylated first in the

${ }^{1}$ Institute of Molecular BioMedicine, Medical Faculty, Comenius University, Bratislava, Slovakia, ${ }^{2}$ Department of Clinical and Experimental Pharmacotherapy, Medical Faculty, Slovak Medical University, Bratislava, Slovakia, ${ }^{3}$ Paediatric Department, Faculty of Medicine, P.J. Šafárik University, Košice, Slovakia, and ${ }^{4} 1$ st Paediatric Department, Medical Faculty, Comenius University, Bratislava, Slovakia

Address for correspondence: K. Sebekova, MD, DSc, Institute of Molecular BioMedicine, Medical Faculty, Comenius University, Sasinkova 4, SK-811 08 Bratislava, Slovakia.

Phone: +421.2.59357429, Fax: +421.2.59357631

Acknowledgement: This work was supported by the Scientific Grant Agency of the Ministry of Education, Science, Research and Sport of the Slovak Republic and Slovak Academy of Sciences (VEGA grant No. 1/0715/11 to LP). This article was created by realization of the project "Centre of excellence of environmental health", ITMS No. 26240120033, based on the supporting operational Research and Development Program financed from the European Regional Development Fund. liver to form $25(\mathrm{OH}) \mathrm{D}_{3}$, and thereafter in the kidneys to produce the active vitamin in form of $1,25(\mathrm{OH})_{2} \mathrm{D}_{3}$.

The effects of active vitamin $\mathrm{D}$ are mediated predominantly by binding to its nuclear receptor (VDR). Together with other transcription factors such as retinoid X receptor (RXR), the complex of vitamin D, VDR and RXR is formed and bound to vitamin D response elements of multiple genes, regulating directly and/or indirectly their expression (1-3).

The effects of vitamin $\mathrm{D}$ on skeleton, its role in proper hormone secretion, and functioning of neural transmission and neuromuscular junctions have been well known for a long time $(2,4,5)$.

Recently, it has been recognized that $1,25(\mathrm{OH})_{2} \mathrm{D}_{3}$ is produced locally in a wide variety of extrarenal cells expressing VDR. It is presumed that local production of vitamin $\mathrm{D}$ is responsible for extraskeletal modulation of various physiological processes with a series of adverse consequences associated with inadequate $1,25(\mathrm{OH})_{2} \mathrm{D}_{3}$ production, such as increased risk of hypertension, insulin resistance, type 1 and 2 diabetes, and different cancers (2, 6). Current evidence suggests that $25(\mathrm{OH}) \mathrm{D}_{3}$ levels above $30 \mathrm{ng} / \mathrm{ml}$ may potentially exert non-calcemic health benefits. As documented in the large prospective study, inadequate vitamin D levels $(<15$ $\mathrm{ng} / \mathrm{ml}$ ) represent an important cardiovascular $(\mathrm{CV})$ risk factor and might play a causal role in the development of CV risk factors, 
CV diseases and adverse events including death (7). An increased CV mortality of vitamin D-deficient subjects was confirmed also by the recent meta-analysis (8). A significant relationship between vitamin $\mathrm{D}$ deficiency and cardiometabolic risk factors has been documented even in obese children and adolescents (9).

Among EU countries, the prevalence of overweight, obesity and hypertension are highest in Slovakia, and they associate with unfavorable nutrition, smoking, and a lack of physical activity (10-12). The high prevalence of CV disease risk factors is reflected by one of the highest CV mortality rates of Slovak adults among 27 EU countries $(11,13)$.

We posed a question whether in apparently healthy medication-free Slovaks, the vitamin D status deteriorates by ageing, and how it is associated with CV risk factors (BP, overweight/obesity, physical activity, smoking status), and their combination.

\section{Subjects and methods}

This study was conducted according to Declaration of Helsinki, after the approval of the protocols by ethics boards of SMU in Bratislava and Medical Faculty of UJPŠ in Košice. Participating subjects or their parents (for under-aged) signed written informed consent to participate.

\section{Subjects}

Apparently healthy medication-free volunteers of Central European descent attending their regular preventive examination were recruited via general practitioners, or using advertisements posted in frequented public locations in two Slovak cities with similar geographic latitude: Bratislava: $48.1^{\circ} \mathrm{N}, 17.0^{\circ} \mathrm{E}$, and Košice: $48.4^{\circ} \mathrm{N}, 21.1^{\circ} \mathrm{E}$. Members of minorities with darker skin where not included (14). Further exclusion criteria were age $<5$ years, any acute and/or chronic diseases, unstable health conditions, and pregnancy and lactation in women. Subjects declaring that they were not supplemented by vitamin D (including any over-the-counter vitamin D supplements) during at least last six months underwent complete medical examination by a physician at outpatients departments prior to enrollment.

\section{Measurements}

Body weight was measured using calibrated electronic balance; height was measured using stadiometer. Body mass index (BMI) was calculated. Adults presenting BMI $\leq 24.9 \mathrm{~kg} / \mathrm{m}^{2}$, and children and adolescents in BMI < 90th percentile for their gender and age (15) according to 1991 Slovak charts were considered having normal body weight. Blood pressure readings were taken in the right forearm in sitting subjects resting for at least 10 minutes, using standard sphygmomanometer. The mean of last two readings out of three taken was considered. In adults, systolic BP $(\mathrm{SBP}) \geq 130 \mathrm{~mm} \mathrm{Hg}$ and/or diastolic $\mathrm{BP}(\mathrm{DBP}) \geq 85 \mathrm{~mm} \mathrm{Hg}$ was considered to be a risk factor for cardiometabolic disease (16). In children and adolescents, BP $>$ 90th percentile for gender, height and age was considered elevated (17).

Blood was sampled after overnight fasting. Serum was stored at $-80{ }^{\circ} \mathrm{C}$ till analysis. Concentrations of $25(\mathrm{OH}) \mathrm{D}_{3}$ were deter- mined by RIA method $\left(25(\mathrm{OH}) \mathrm{D}_{3}\right.$, Immuno Diagnostic system, Boldon, UK) at SMU. Intra- and inter-batch coefficients of variation were $<10 \%$. The state of $25(\mathrm{OH}) \mathrm{D}_{3}$ deficiency was considered at concentrations $\leq 20 \mathrm{ng} / \mathrm{ml}$; insufficiency was considered at levels ranging between 20 and $30 \mathrm{ng} / \mathrm{ml}$, while higher levels were considered satisfactory (5).

Self-reported current smoking status was recorded as "yes" or "no". Subjects reporting physical activity for longer than $30 \mathrm{~min} /$ /day at least 3 times per week were classified as physically active; those not exercising at all or reporting less frequent shorter physical activity were classified as sedentary. Physical activity comprehended exercising, cycling, dancing, gardening, etc.

\section{Statistical analyses}

Data not matching the normal distribution were logarithmically (ln) transformed for statistical evaluation, but for better understanding, mean \pm standard deviation $(\mathrm{x} \pm \mathrm{SD})$ are given. Means of two groups were compared using Student's t-test; three groups were compared using analysis of variance (ANOVA) with posthoc Scheffe's test, if appropriate. Chi-square test (with Yates' correction where appropriate) was used to compare categorical data. Pearson's or Spearman's correlation coefficients were calculated.

Tab. 1. Cohort characteristics and $25(\mathrm{OH}) \mathrm{D}_{3}$ levels with regards to smoking status, body weight, physical activity and blood pressure in whole cohort, males and females.

\begin{tabular}{lcccc}
\hline & All & Males & Females & $\mathrm{p}$ \\
\hline $\mathrm{N}(\%)$ & 578 & $254(44 \%)$ & $324(56 \%)$ & - \\
$\mathrm{Age}($ years $)$ & $33.81 \pm 14.7$ & $34.0 \pm 15.0$ & $33.7 \pm 14.5$ & 0.81 \\
$\mathrm{BMI}\left(\mathrm{kg} / \mathrm{m}^{2}\right)$ & $24.8 \pm 5.0$ & $26.3 \pm 5.0$ & $23.7 \pm 4.7$ & $<0.001$ \\
$\mathrm{SBP}(\mathrm{mm} \mathrm{Hg})$ & $123 \pm 14$ & $128 \pm 14$ & $120 \pm 13$ & $<0.001$ \\
$\mathrm{DBP}(\mathrm{mm} \mathrm{Hg})$ & $76 \pm 9$ & $77 \pm 9$ & $75 \pm 9$ & 0.003 \\
\hline
\end{tabular}

Vitamin D concentrations

\begin{tabular}{lcccc}
\hline $25(\mathrm{OH}) \mathrm{D}_{3}(\mathrm{ng} / \mathrm{ml})$ & $35.6 \pm 16.8$ & $35.1 \pm 17.2$ & $36.0 \pm 16.4$ & 0.48 \\
\hline Smoking status & & & & \\
\hline Current non-smokers & $36.6 \pm 17.0$ & $36.1 \pm 17.2$ & $37.0 \pm 17.0$ & 0.76 \\
Current smokers & $34.0 \pm 16.4$ & $33.6 \pm 18.4$ & $34.3 \pm 14.8$ & 0.42 \\
$\mathrm{p}$ & 0.11 & 0.14 & 0.40 & - \\
\hline Body mass index & & & & \\
\hline Normal & $35.7 \pm 16.8$ & $34.8 \pm 17.1$ & $36.3 \pm 16.6$ & 0.29 \\
Overweight/obese & $35.2 \pm 16.4$ & $36.4 \pm 17.7$ & $33.3 \pm 14.3$ & 0.48 \\
$\mathrm{p}$ & 0.80 & 0.55 & 0.35 & - \\
\hline Physical activity & & & & \\
\hline Physically active & $38.0 \pm 17.0$ & $37.0 \pm 17.8$ & $38.8 \pm 16.4$ & 0.26 \\
Sedentary & $33.4 \pm 16.4$ & $33.1 \pm 16.8$ & $33.5 \pm 16.2$ & 0.78 \\
p & $<0.001$ & 0.045 & 0.002 & - \\
\hline Blood pressure & & & & \\
\hline Normotensive subjects & $36.3 \pm 16.7$ & $36.5 \pm 18.8$ & $36.2 \pm 15.5$ & 0.84 \\
Elevated blood pressure & $3451 \pm 16.9$ & $33.9 \pm 15.6$ & $35.4 \pm 18.8$ & 0.69 \\
p & 0.22 & 0.37 & 0.53 & - \\
\hline
\end{tabular}

BMI: body mass index; SBP: systolic blood pressure; DBP: diastolic blood pressure; $25(\mathrm{OH}) \mathrm{D}_{3}$ : 25-hydroxy vitamin $\mathrm{D}_{3}$; chi: chi-square; italics: statistical evaluation performed on logarithmically transformed data; normal weight classified as BMI $<95$ th percentile for age and gender in children and adolescents, and BMI $\leq 24.9 \mathrm{~kg} / \mathrm{m}^{2}$ in adults; overweight/obesity classified as BMI $\geq 95$ th percentile for age and gender in children and adolescents, and $\mathrm{BMI} \geq 25.0 \mathrm{~kg} / \mathrm{m}^{2}$ in adults; subjects reporting physical activity lasting at least $30 \mathrm{~min}$ for at least 3 times per week were classified as physically active; subjects not exercising at all or reporting less frequent and shorter physical activity were classified as sedentary; elevated blood pressure was classified as $\mathrm{SBP} \geq 130 \mathrm{~mm} \mathrm{Hg}$ and/or DBP $\geq 85 \mathrm{~mm} \mathrm{Hg}$ in adults and blood pressure $>95$ th percentile for gender, height and age in children and adolescents 


\section{2-709}

Multivariate analysis employing General linear model (GLM) and classification tree with season of blood sampling entered as an influence variable were employed to study the impact of independent variables on $25(\mathrm{OH}) \mathrm{D}_{3}$ levels. Only subjects aged $\geq 18$ years in whom data on all risk factors were available were included. The value of $\mathrm{p}<0.05$ (2-sided) was considered significant. Statistical analyses were performed using program SPSS version 22 (SPSS Inc., Chicago, IL, USA). In addition, software for orthogonal projections to latent structures analysis (OPLS, Simca v.14.1 software, Umetrics, Umea, Sweden) was used to identify the predictors of $25(\mathrm{OH}) \mathrm{D}_{3}$ levels. Variables with variable of importance for the projection (VIP) values $>1$ were considered to be important contributors, while those with VIP $<0.5$ were considered unimportant. VIP values in range of $0.5-1$ are generally considered to be in "grey interval"; the importance of variable depends on the sample size.

\section{Results}

\section{General characteristics}

Out of 589 recruited subjects, 11 in whom the $25(\mathrm{OH}) \mathrm{D}_{3}$ levels were not determined for technical reasons were not included into this analysis. Thus, the cohort consisted of 578 apparently healthy subjects aged 5-81 years; characteristics are given in Table 1. A proportion of $38 \%$ of subjects presented elevated BP with higher prevalence among males (53\%) in comparison with females $(27 \%$, $\left.\mathrm{p}_{\text {chi }}<0.001\right)$. Subjects with elevated BP were older than their normotensive counterparts $(42.1 \pm 15.6$ vs $28.6 \pm 11.3$ years; $p>0.001)$. A proportion of $18 \%$ of participants were overweight or obese with higher prevalence among males (24\%) than among females (12 $\left.\% ; \mathrm{p}_{\text {chi }}<0.001\right)$. Those presenting overweight/obesity were older than their lean counterparts $(43.9 \pm 15.8$ vs $31.6 \pm 13.4$ years; $p>$ 0.001 ). Data on smoking status were not available from 31 children/ adolescents and 7 adults. Out of 540 subjects evaluated for smoking status, $77 \%$ were current non-smokers, while the prevalence of non-smokers did not differ between genders ( $77 \%$ vs $77 \%$, $\mathrm{p}_{\text {chi }}=$ $0.97)$. Smokers and non-smokers were of similar age (34.8 \pm 13.1 vs $34.1 \pm 15.1$ years; $p=0.64)$. Thirty-eight children/adolescents were not included into the analysis on the effects of physical exercise. Out of 540 evaluated subjects, $57 \%$ were exercising regularly; sedentary life style was less frequent among males (38 \%) in comparison with females $\left(47 \% ; p_{\text {chi }}=0.033\right)$. Physically active and sedentary subjects were of similar age $(38.0 \pm 17.0$ vs $33.4 \pm$ 16.4 years; $p=0.31$ ).

\section{$25(\mathrm{OH}) \mathrm{D}_{3}$ levels}

Seasonal variation

$25(\mathrm{OH}) \mathrm{D}_{3}$ levels ranged between $2.5 \mathrm{ng} / \mathrm{ml}$ and $141.7 \mathrm{ng} / \mathrm{ml}$. The annual average was $35.6 \pm 16.8 \mathrm{ng} / \mathrm{ml}$ without significant difference between males and females (Tab. 1). Variation in mean levels throughout the year is given in Figure 1a. Eighty-seven participants $(15 \%)$ were $25(\mathrm{OH}) \mathrm{D}_{3}$-deficient with $25(\mathrm{OH}) \mathrm{D}_{3}$ levels averaging $15.3 \pm 3.6 \mathrm{ng} / \mathrm{ml}$, while 151 subjects $(26 \%)$ presented insufficient $(25.1 \pm 2.8 \mathrm{ng} / \mathrm{ml})$ and $59 \%$ satisfactory $25(\mathrm{OH}) \mathrm{D}_{3}$ levels $(45.5 \pm$ $14.8 \mathrm{ng} / \mathrm{ml})$. The prevalence of $25(\mathrm{OH}) \mathrm{D}_{3}$ deficiency, insufficiency, and satisfactory levels throughout the year are given in Figure $1 \mathrm{~b}$.
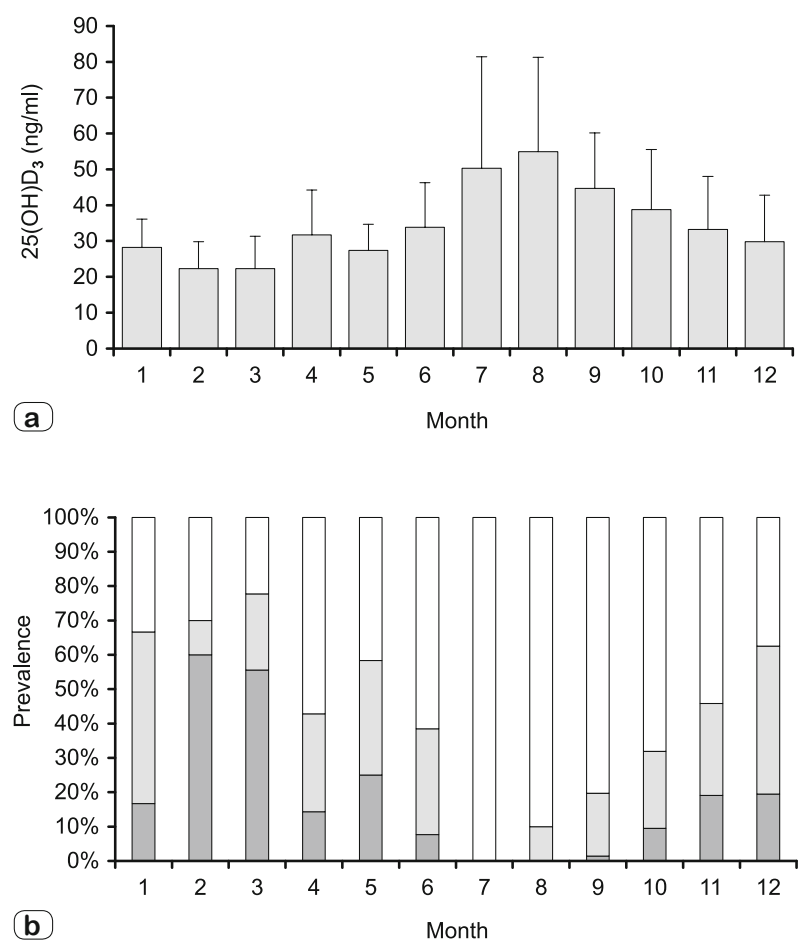

$\square$ 25(OH)D3<20 ng/ml $\square$ 25(OH)D3:20-30 ng/ml $\square$ 25(OH)D3>30 ng/ml

Fig. 1. Seasonal variation in $25(\mathrm{OH}) \mathrm{D}_{3}$ levels and in prevalence of $25(\mathrm{OH}) \mathrm{D}_{3}$ deficiency $(\leq 20 \mathrm{ng} / \mathrm{ml})$, insufficiency $\left(25(\mathrm{OH}) \mathrm{D}_{3}\right.$ concentration in range $20-30 \mathrm{ng} / \mathrm{ml})$, and satisfactory levels $\left(25(\mathrm{OH}) \mathrm{D}_{3}>30\right.$ $\mathrm{ng} / \mathrm{ml})$. 1a: Seasonal variation in mean $25(\mathrm{OH}) \mathrm{D}_{3}$ levels, $1 \mathrm{~b}$ : Seasonal variation in the prevalence of $25(\mathrm{OH}) \mathrm{D}_{3}$ deficiency, insufficiency and satisfactory levels 1: January; 2: February; 3: March; 4: April; 5: May; 6: June; 7: July; 8: August; 9: September; 10: October; 11: November; 12: December.

\section{Effects of ageing}

Mean $25(\mathrm{OH}) \mathrm{D}_{3}$ levels were similar among age groups $\left(\mathrm{p}_{\mathrm{ANO}}\right.$ $\mathrm{vA}_{\mathrm{A}}=0.48$ ) (Fig. 2a). Neither the prevalence of $25(\mathrm{OH}) \mathrm{D}_{3}$ insufficiency, deficiency or satisfactory levels differed significantly (Fig. 2b) $\left(\mathrm{p}_{\text {chi-Yates }}=0.76\right)$.

\section{Effect of single risk factor}

Current smoking status or presence of overweight/obesity did not affect $25(\mathrm{OH}) \mathrm{D}_{3}$ levels significantly in the whole cohort, either in males or in females (Tab. 1). Significant relationship between $\ln 25(\mathrm{OH}) \mathrm{D}_{3}$ and BMI was revealed only in overweight/obese subjects $(r=-0.209 ; p=0.035)$. The prevalence of $25(\mathrm{OH}) \mathrm{D}_{3}$ deficiency, insufficiency, and satisfactory levels was similar in overweight/obese vs. lean subjects $\left(\mathrm{p}_{\text {chi }}=0.55\right)$ as well as in smokers vs. nonsmokers $\left(\mathrm{p}_{\text {chi }}=0.28\right)$. Although our subjects presenting elevated vs. normal $\mathrm{BP}$ did not differ in $25(\mathrm{OH}) \mathrm{D}_{3}$ levels significantly (Tab. 1), the prevalence of $25(\mathrm{OH}) \mathrm{D}_{3}$ deficiency, insufficiency and satisfactory levels differed significantly (normotensive subjects: $12 \%, 25 \%$ and $63 \%$, respectively; subjects with elevated blood pressure: $20 \%, 27 \%$, and $53 \%$, respectively; $\mathrm{p}_{\text {chi }}=0.018$ ). Physically active subjects presented significantly higher $25(\mathrm{OH}) \mathrm{D}_{3}$ lev- 

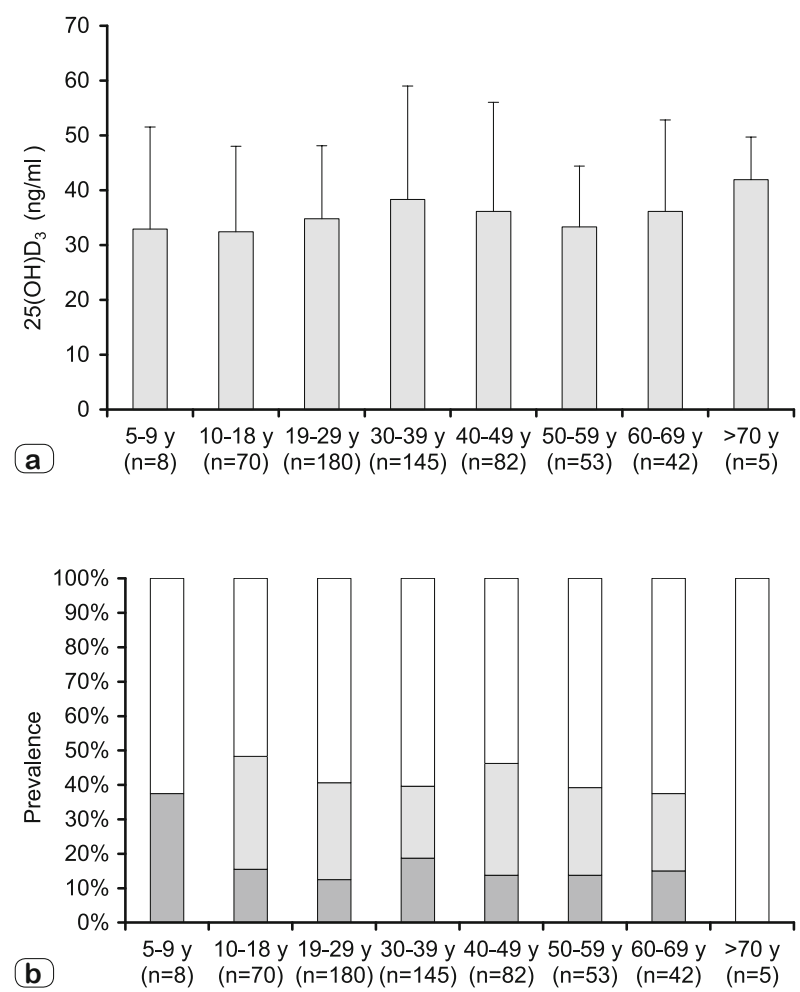

$\square$ 25(OH)D3<20 ng/ml $\square$ 25(OH)D3:20-30 ng/ml $\square 25(\mathrm{OH}) \mathrm{D} 3>30 \mathrm{ng} / \mathrm{ml}$

Fig. 2. Serum $25(\mathrm{OH}) \mathrm{D}_{3}$ concentrations and prevalence of $25(\mathrm{OH}) \mathrm{D}_{3}$ deficiency $(\leq 20 \mathrm{ng} / \mathrm{ml})$, insufficiency $\left(25(\mathrm{OH}) \mathrm{D}_{3}\right.$ concentration in range $20-30 \mathrm{ng} / \mathrm{ml})$, and satisfactory levels $\left(25(\mathrm{OH}) \mathrm{D}_{3}>30 \mathrm{ng} / \mathrm{ml}\right)$ according to age categories. $2 \mathrm{a}$ : Mean $25(\mathrm{OH}) \mathrm{D}_{3}$ concentrations according to age categories $\left(\mathrm{p}_{\mathrm{ANOVA}}=0.48\right)$, 2b: Prevalence of $25(\mathrm{OH}) \mathrm{D}_{3}$ deficiency, insufficiency and satisfactory levels in different age categories, y: years.

els in comparison with their sedentary counterparts both in males and females (Tab. 1). Higher levels in physically active subjects were evident throughout the year, reaching significance in period from October-to-March (Fig. 3). The prevalence of 25(OH) $\mathrm{D}_{3}$ deficiency, insufficiency, and satisfactory levels differed significantly between the sedentary participants $(19 \%, 29 \%$ and $52 \%$, respectively) in comparison with their exercising counterparts (11\%, $24 \%$ and $65 \%$, respectively; $\left.\mathrm{p}_{\text {chi }}=0.006\right)$. The prevalence of overweight/obesity was significantly higher among sedentary vs physically active subjects ( $25 \%$ vs $12.3 \%$; $\mathrm{p}_{\text {chi }}>0.001$ ), while that of elevated BP (42.2\% vs $37.7 \%$; $=0.28)$ and active smokers ( $26.3 \%$ vs $21.8 \% ; p=0.22)$ did not differ significantly.

\section{Interaction of risk factors}

GLM and OPLS models were used to test the effects of presence/absence of the risk factors on $25(\mathrm{OH}) \mathrm{D}_{3}$ levels. OPLS indicated that the risk factors as independent predictors explain only $3 \%$ in the variability of $25(\mathrm{OH}) \mathrm{D}_{3}$. The presence of physical activity and leanness was associated significantly with higher $25(\mathrm{OH})$ $\mathrm{D}_{3}$ levels (VIP values 1.47 and 1.03, respectively). GLM selected interactions as being significant as follows: interactions between

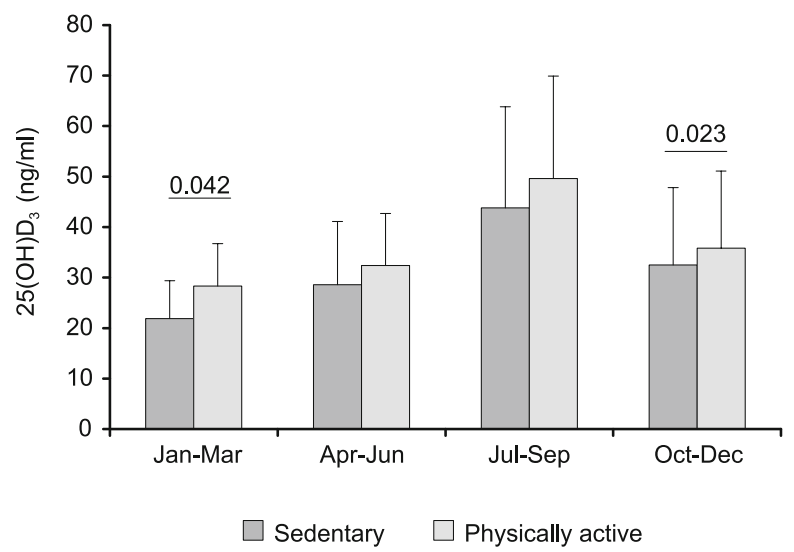

Fig. 3. Seasonal variation in serum $25(\mathrm{OH}) \mathrm{D}_{3}$ levels in sedentary and physically active adults. Sed.: sedentary subjects; PA: physically active subjects, e.g. exercising at least 3 times a week for minimally 30 min; Jan-Mar: January-to-March; Apr-Jun: April-to-June; Jul-Sep: July-to-September; Oct-Dec: October-to-December.

presence/absence of physical activity, overweight/obesity, and smoking (overall model $\mathrm{p}=0.024$; interaction between physical activity and smoking: $\mathrm{p}=0.029$; physically active non-smokers: beta: -69 , SE: 0.32 ; interaction between physical activity, overweight/obesity and smoking: $\mathrm{p}=0.020$; physically active lean nonsmokers: beta: -0.89 ; SE: $\left.0.38 ; \mathrm{R}^{2}=0.025\right)$. The effect of interaction of the risk factors was further analyzed employing the answer tree with season of blood sampling used as an influence variable.

The model selected physical activity as the main determinant of $25(\mathrm{OH}) \mathrm{D}_{3}$ levels (Fig. 4), confirming higher $25(\mathrm{OH}) \mathrm{D}_{3}$ levels in physically active subjects vs. their sedentary counterparts.

In physically active subjects, BP was the second influencing risk factor while elevated $\mathrm{BP}$ was associated with lower $25(\mathrm{OH}) \mathrm{D}_{3}$ levels. In the next nodes, the model designated the smoking status as the influencing variable in both BP categories of physically active subjects with lower $25(\mathrm{OH}) \mathrm{D}_{3}$ levels in current smokers.

In sedentary subjects, the model denoted overweight/obesity as the determinant of lower $25(\mathrm{OH}) \mathrm{D}_{3}$ levels. Further analysis confirmed that smoking (non-smokers: $\mathrm{n}=171,33.5 \pm 15.9$; smokers: $\mathrm{n}=61,33.0 \pm 17.9 \mathrm{ng} / \mathrm{ml}, \mathrm{p}=0.65$ ) or elevated BP (normotension: $\mathrm{n}=134,33.6 \pm 14.8$; elevated BP: $\mathrm{n}=98,33.0 \pm 18.5$ $\mathrm{ng} / \mathrm{ml}, \mathrm{p}=0.57)$ were associated with a tendency towards lower $25(\mathrm{OH}) \mathrm{D}_{3}$ levels even among sedentary subjects. Physically active normotensive non-smokers presented the highest levels, while the physically active smokers with elevated BP and overweight/ obese sedentary subjects had the lowest $25(\mathrm{OH}) \mathrm{D}_{3}$ levels (Fig. 4). Forcing the gender as an independent variable into the model did not affect the results.

\section{Discussion}

Apparently healthy medication-free Slovaks presented commonly low $25(\mathrm{OH}) \mathrm{D}_{3}$ levels and a high prevalence of hypovitaminosis D, regardless of their age. Physical activity appeared to be the main determinant of favorable vitamin D status. Clustering of 


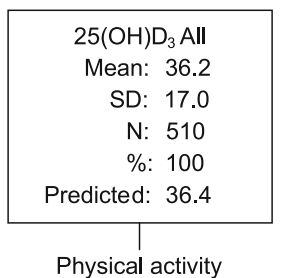

Adj. P.: 0.001; $F=19.2 ;$ df1: 1; df2: 1757

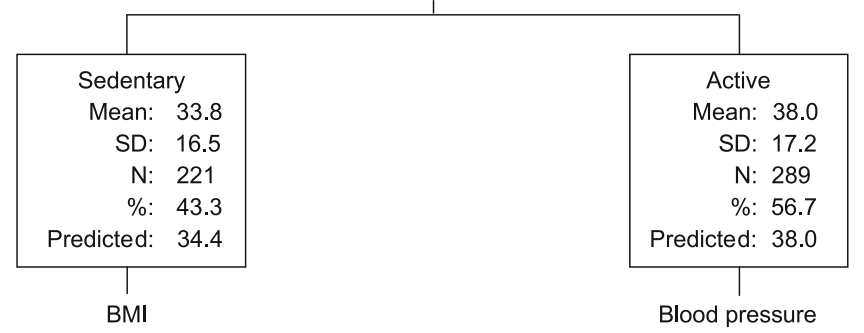

Adj. P.: 0.018; F= 5.6; df1: 1; df2: 756

Adj. P.: 0.001; F = 14.3; df1: 1; df2: 999

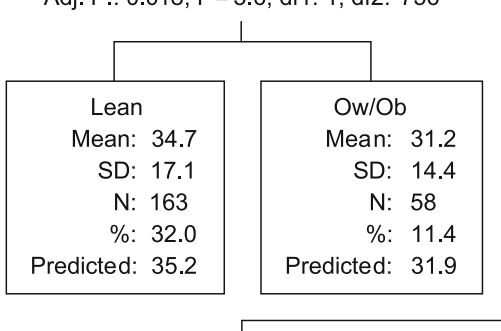

Smoking status

Adj. P.: 0.002; $F=9.9 ;$ df1: 1; df2: 387
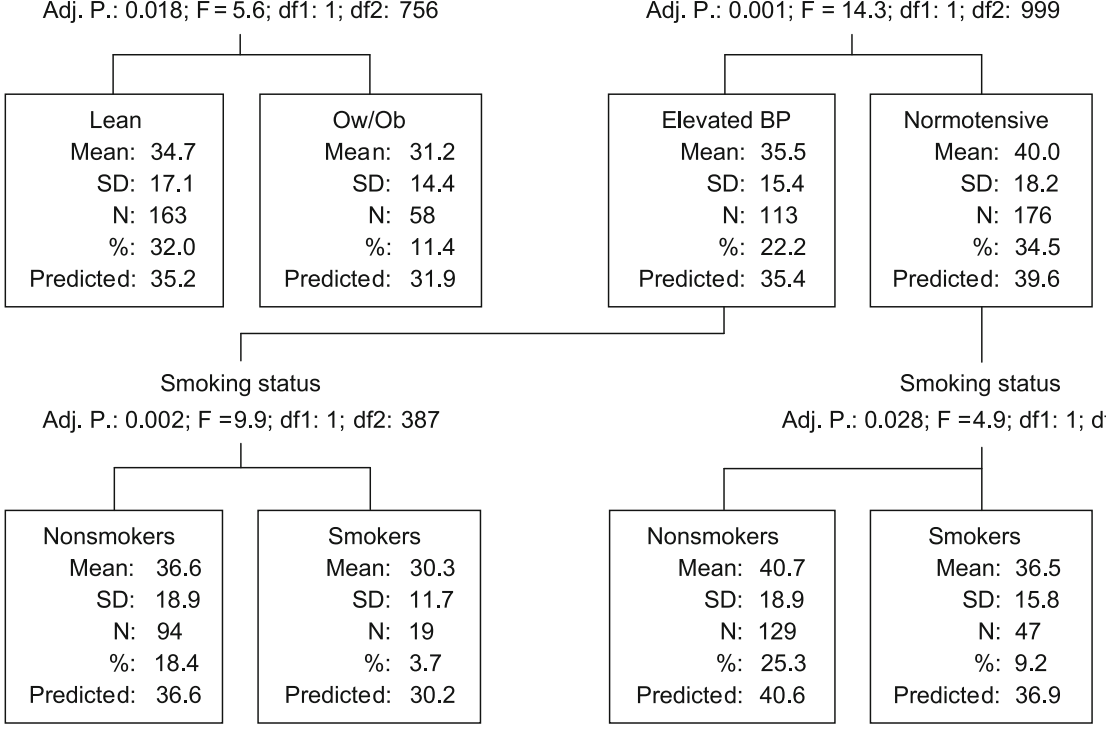

Adj. P.: 0.028; F =4.9; df1: 1; df2: 610

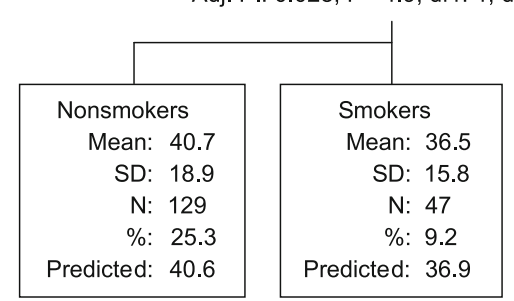

Fig. 4. Decision tree - impact of physical activity, overweight/obesity, blood pressure and smoking status on $25(\mathrm{OH}) \mathrm{D}_{3}$ levels in adults $(\geq 19$ years). Std. Dev.: standard deviation; Adj.: adjusted; BMI: body mass index; Lean: BMI $\leq 24.9$ kg/m²; Ow/ob: overweight and obese, BMI $>$ $25.0 \mathrm{~kg} / \mathrm{m}^{2}$; BP: blood pressure; elevated blood pressure classified as systolic BP $\geq 130 \mathrm{~mm} \mathrm{Hg}$ and/or diastolic BP $\geq 85 \mathrm{~mm} \mathrm{Hg}$; normotension classified as systolic $\mathrm{BP}<130 \mathrm{~mm} \mathrm{Hg}$ and/or diastolic $\mathrm{BP}<85 \mathrm{~mm} \mathrm{Hg}$.

risk factors, rather than the presence of a single risk factor per se, was associated with unfavorable vitamin D status. However, the studied risk factors (e.g. sedentary life style, overweight/obesity, elevated BP and current smoking) explained only minor variability in $25(\mathrm{OH}) \mathrm{D}_{3}$ levels.

\section{$25(\mathrm{OH}) \mathrm{D}_{3}$ status}

As follows from the recent review on vitamin D status in Central Europe (18), only 2 studies in general adult population from countries neighboring Slovakia (i.e. Czech Republic, Hungary, Poland, Ukraine) reported mean levels of 25(OH) $\mathrm{D}_{3}<30 \mathrm{ng} / \mathrm{ml}(19,20)$. Data on vitamin $\mathrm{D}$ status in general Slovak population are not available. Another Slovak study tackling vitamin D status in apparently healthy subjects (pre- menopausal 25-40 years old women with normal bone mineral density) reported similar mean $25(\mathrm{OH}) \mathrm{D}_{3}$ levels $(33 \pm 13$ $\mathrm{ng} / \mathrm{ml})$, as well as a similar prevalence of satisfactory $25(\mathrm{OH})$ $\mathrm{D}_{3}$ levels $(51 \%)$ to those observed in our study (21). On the other hand, small clinical studies (on type 1 diabetic children, patients with Down syndrome, patients in stages $2-3$ of chronic kidney disease, patients with pulmonary sarcoidosis, post-menopausal women with osteopenia/osteoporosis, or elderly subjects with metabolic syndrome) reported median $25(\mathrm{OH}) \mathrm{D}_{3}$ levels in range 19-30 $\mathrm{ng} / \mathrm{ml}$, and low prevalence of satisfactory levels (9-36\%) (22-27). Thus, it might be expected that in general Slovak population, mean $25(\mathrm{OH}) \mathrm{D}_{3}$ levels as well as the prevalence of satisfactory $25(\mathrm{OH}) \mathrm{D}_{3}$ status would be much lower than those observed in apparently healthy volunteers. Further 
larger studies tackling general population and clinical cohorts are definitely needed to objectify vitamin D status in the Slovaks, and its potential association with morbidity and mortality, particularly from $\mathrm{CV}$ diseases and cancer.

\section{$25(\mathrm{OH}) \mathrm{D}_{3}$ and physical activity}

In our cohort, physical activity appeared to be the main determinant of $25(\mathrm{OH}) \mathrm{D}_{3}$ status. The differences between physically active and sedentary subjects were present regardless of the season of blood sampling, especially during winter and early spring. This finding is of particular importance, since in Eurobarometer 2013 , only $34 \%$ of Slovaks declared that they exercise regularly or with some regularity. It remains unclear whether physical activity independent of sun exposure plays a role in modulating $25(\mathrm{OH}) \mathrm{D}_{3}$ levels, or healthy lifestyle of physically active subjects denotes also higher dietary intake of vitamin D from natural sources. In Slovakia, foods are not fortified with vitamin D. However, we tracked neither the question whether exercising was performed indoors or outdoors, nor followed the dietary intake of vitamin $\mathrm{D}$. Higher $25(\mathrm{OH}) \mathrm{D}_{3}$ levels in physically active subjects might also reflect the lower prevalence of overweight/obesity in this cohort. Our data also document that beneficial effects of physical activity on vitamin D status might not completely counteract the negative influence of other risk factors such as elevated $\mathrm{BP}$, and particularly smoking. Similar interactions might underlie discrepant results in studies on $25(\mathrm{OH}) \mathrm{D}_{3}$ levels in subjects practicing regular physical activity in comparison with their sedentary counterparts (28-31).

\section{$25(\mathrm{OH}) \mathrm{D}_{3}$ and blood pressure}

Vitamin D may contribute to BP control via modulation of different metabolic pathways, such as absorption of calcium from the gut; effects on the renin-angiotensin system, endothelial function and arterial stiffness, or development of insulin resistance predisposing to hypertension (32-34). Large cross-sectional observational studies have linked low $25(\mathrm{OH}) \mathrm{D}_{3}$ levels with increased $\mathrm{BP}$ (35). On the other hand, the antihypertensive effects of vitamin D supplementation are ambiguous $(36,37)$. In our study, normotension was generally associated with a tendency towards higher $25(\mathrm{OH}) \mathrm{D}_{3}$ levels, but elevated BP showed a significant negative impact on $25(\mathrm{OH}) \mathrm{D}_{3}$ levels only in physically active subjects. The reasons are unclear, but our findings indicate that in apparently healthy subjects, several other factors modulate the association of $25(\mathrm{OH}) \mathrm{D}_{3}$ levels with BP.

\section{$25(\mathrm{OH}) D_{3}$ and overweight/obesity}

The current evidence links overweight and obesity to poorer vitamin D status $(38,39)$. However, the overall strength of the consistent inverse association between overweight/obesity and low vitamin D status is usually weak (38). Potential mechanisms suggest sequestration of $25(\mathrm{OH}) \mathrm{D}_{3}$ in adipose tissue, volumetric dilution, negative feedback mechanisms from increased circulating 1,25-dihydroxyvitamin D3, or decreased endogenous production of cholecalciferol in the skin due to lesser outdoor activities of heavier individuals potentially wearing more clothing (38). In our study overweight/obesity was associated with lower $25(\mathrm{OH}) \mathrm{D}_{3}$ levels only in sedentary subjects. On one hand, this might reflect the higher prevalence of overweight/obesity in sedentary subjects. On the other hand, the contribution of life-style factors such as sun exposure, dietary vitamin D intake, and other ones not tracked in our study cannot be excluded.

\section{$25(\mathrm{OH}) D_{3}$ and smoking}

In large cross-sectional studies, smoking is generally but not unequivocally, associated with lower mean $25(\mathrm{OH}) \mathrm{D}_{3}$ levels or higher prevalence of vitamin D deficiency $(29,30,40,41)$. The exact mechanisms by which the constituents of tobacco smoke affect vitamin D metabolism are still unclear, but adverse effects on the level of $25(\mathrm{OH}) \mathrm{D}_{3}$ synthesis are anticipated (42). In smokers, less sun exposure due to shorter outdoor activities might also not be excluded (41). Although in our study, smoking was significantly associated with lower $25(\mathrm{OH}) \mathrm{D}_{3}$ levels only in physically active subjects, the tendency towards lower levels was observed also in their sedentary counterparts. However, we neither stratified for daily number of smoked cigarettes or for passive exposure to cigarette smoke, nor recorded potential smoking cessation during last few months. We also might speculate that in apparently healthy subjects, the sedentary life style per se is the major determinant of vitamin D status. Thus, our finding requires further targeted studies.

\section{Strengths and limitations}

This is the first study in Slovakia on vitamin D status in apparently healthy subjects of both genders and in a wide age range - from childhood to the elderly. Elderly subjects were not institutionalized. As our volunteers were virtually all of Central European descent, residing in Bratislava or Košice region, the intersubject variability in regard to sun exposure and darkness of the skin is likely to be small. However, our volunteers were not completely unrelated, i.e. close relatives have participated. Our data on elevated blood pressure might be partially elusive because they were based on single measurements in subjects declaring that they had not been diagnosed and treated for hypertension. Voluntary participation and inclusion of apparently healthy medicationfree subjects indicate that our data reflect the status in an "overhealthy" population. The number of enrolled subjects aged over 60 years was low, reflecting that seniors generally suffer from different diseases and are on medication. Another limitation is that we used simple self-report to quantify physical activity and smoking status. Physical activity was not tracked in pre-school children and those attending primary schools. In the latter ones, due to the fact that pupils attending schools providing $>2$ classes of gym per week would automatically classify as physically active. Missing data and (as expected) low prevalence of risk factors in children/adolescents did not allow for separate analysis of associations in this cohort. Moreover, the cross-sectional nature of the study requires caution in interpreting the associations delineated. Additional limitations are discussed above in relation to pertinent subject. 
702-709

\section{Conclusion}

Our cross-sectional data suggest that in apparently healthy subjects, vitamin D status does not deteriorate in the course of healthy ageing, and underline the association of physical activity, absence of overweight/obesity, and non-smoking status with satisfactory vitamin D levels. Unsatisfactory vitamin D status is associated with the clustering of cardiovascular risk factors. However, the investigated risk factors explained only a minor proportion in the variability of $25(\mathrm{OH}) \mathrm{D}_{3}$ levels. Thus, whether the introduction of regular physical activity, reduction of body fatness, and smoking cessation could effectively improve vitamin D status at least for subjects presenting a particular clustering of cardiovascular risk factors remains to be elucidated.

\section{References}

1. DeLuca HF. History of the discovery of vitamin D and its active metabolites. BoneKEy Rep 2014; 3: Article number: 479.

2. Norman AW. From vitamin D to hormone D: fundamentals of the vitamin D endocrine system essential for good health. Am J Clin Nutr 2008; 88 (2): 491S-499S.

3. Hossein-nezhad A, Spira A, Holick MF. Influence of Vitamin D Status and Vitamin D-3 Supplementation on Genome Wide Expression of White Blood Cells: A Randomized Double-Blind Clinical Trial. PloS one 2013; 8 (3): e58725.

4. Girgis CM, Clifton-Bligh RJ, Hamrick MW, Holick MF, Gunton JE. The Roles of Vitamin D in Skeletal Muscle: Form, Function, and Metabolism. Endocr Rev 2013; 34 (1): 33-83.

5. Holick MF. Vitamin D deficiency. N Engl J Med.2007; 357 (3): 266-281.

6. Pittas AG, Dawson-Hughes B. Vitamin D and diabetes. J Steroid Biochem Mol Biol 2010; 121 (1-2): 425-429.

7. Anderson JL, May HT, Horne BD et al. Relation of Vitamin D Deficiency to Cardiovascular Risk Factors, Disease Status, and Incident Events in a General Healthcare Population. Am J Cardiol. 2010; 106 (7): 963-968.

8. Schottker B, Jorde R, Peasey A et al. Vitamin D and mortality: metaanalysis of individual participant data from a large consortium of cohort studies from Europe and the United States. BMJ 2014; 348: g3656.

9. Kelishadi R, Salek S, Salek M, Hashemipour M, Movahedian M. Effects of vitamin D supplementation on insulin resistance and cardiometabolic risk factors in children with metabolic syndrome: a triple-masked controlled trial. J Pediatr (Rio J) 2014; 90 (1): 28-34.

10. Mueller-Nordhorn J, Binting S, Roll S, Willich SN. An update on regional variation in cardiovascular mortality within Europe. Eur Heart J 2008; 29 (10): 1316-1326.

11. Nichols M, Townsend N, Luengo-Fernandez R, et al. European Cardiovascular Disease Statistics 2012. European Heart Network, Brussels; European Society of Cardiology, Sophia Antipolis. 2012.

12. Hujova Z, Rostakova K. Several anthropometric predictors of cardiovascular disease in central Slovakian adults: socioeconomic and educational differences. Bratisl Med J 2013; 114 (1): 31-35.

13. Nichols M, Townsend N, Scarborough P, Rayner M. Cardiovascular disease in Europe 2014: epidemiological update. Eur Heart J 2014; 35 (42): 2950-2959.
14. Clemens TL, Adams JS, Henderson SL, Holick MF. Increased skin pigment reduces the capacity of skin to synthesise vitamin D3. Lancet 1982; 1: 74-76.

15. Zimmet P, George K, Alberti MM, et al. The metabolic syndrome in children and adolescents - an IDF consensus report. Pediat Diabet 2007; 8 (5): 299-306.

16. Alberti K, Eckel RH, Grundy SM, et al. Harmonizing the Metabolic Syndrome A Joint Interim Statement of the International Diabetes Federation Task Force on Epidemiology and Prevention; National Heart, Lung, and Blood Institute; American Heart Association; World Heart Federation; International Atherosclerosis Society; and International Association for the Study of Obesity. Circulation 2009; 120 (16): 1640-1645.

17. Cook S, Weitzman M, Auinger P, Nguyen M, Dietz WH. Prevalence of a metabolic syndrome phenotype in adolescents - Findings from the Third National Health and Nutrition Examination Survey, 1988-1994. Arch Pediatr Adolesc Med 2003; 157 (8): 821-827.

18. Pludowski P, Grant WB, Bhattoa HP, et al. Vitamin D Status in Central Europe. Intern J Endocrinol 2014; 2014: 589587.

19. Holecki M, Zahorska-Markiewicz B, Chudek J, Wiecek A. Changes in bone mineral density and bone turnover markers in obese women after short-term weight loss therapy during a 5-year follow-up. Pol Arch Med Wewn 2010; 120 (7-8): 248-254.

20. Vosatkova M, Hoskovcova P, Bilek R. Vitamin D and its metabolitessupply of patients with various endocrine disorders and comparison of analytical methods. Endocr Regul 2007; 41 (1): 19-28.

21. Masaryk P, Letkovská A, Stecová A et al. Prevalence of vitamin D in population of healthy premenopausal women of Slovakia with normal bone mineral density. Rheumatologia 2010; 24 (2): 39-43.

22. Vojtková J, Ciljaková M, Vojarová L, Janíková K, Michnová Z, Sagiová V. Hypovitaminosis D in children with type 1 diabetes mellitus and its influence on biochemical and densitometric parameters. Acta Medica (Hradec Kralove) 2012; 55 (1): 18-22.

23. Šustrová M, Krivošíková Z, Spustová V, Štefíková K. Vitamin D deficite in persons with down syndrome and early prevalence of osteoporosis. Rheumatologia 2008; 22 (3): 87-94.

24. Štefíková K, Spustová V, Krivošíková Z, et al. Insulin resistance and vitamin $\mathrm{D}$ deficiency in patients with chronic kidney disease stage 2-3. Physiol Res 2011; 60 (1): 149-155.

25. Štefíková K, Krivošíková Z, Spustová V, Chylová K, Dzúrik R. Kidney function and age related mineral imbalance in postmenopausal women with osteopenia/osteoporosis. Bratisl Lek Listy 2003; 104 (10): 305-308

26. Brazdilova K, Dlesk A, Koller T, Killinger Z, Payer J. Vitamin D deficiency - a possible link between osteoporosis and metabolic syndrome. Bratisl Lek Listy 2012; 113 (7): 412-416.

27. Bucova M, Suchankova M, Tibenska $\mathbf{E}$ et al. TREM-2 Receptor Expression Increases with $25(\mathrm{OH})$ D Vitamin Serum Levels in Patients with Pulmonary Sarcoidosis. Mediators Inflamm 2015: 2015: 181986.

28. Brock KE, Graubard BI, Fraser DR et al. Predictors of vitamin D biochemical status in a large sample of middle-aged male smokers in Finland. Eur J Clin Nutr 2010; 64 (3): 280-288.

29. Brock K, Huang WY, Fraser DR et al. Low vitamin D status is associated with physical inactivity, obesity and low vitamin D intake in a large US sample of healthy middle-aged men and women. J Steroid Biochem Mol Biol 2010; 121 (1-2): 462-466. 
30. Larose TL, Chen Y, Camargo CA, Langhammer A, Romundstad P, Mai XM. Factors associated with vitamin D deficiency in a Norwegian population: the HUNT Study. J Epidemiol Comm Health 2014; 68 (2): $165-170$.

31. Kolokotroni O, Papadopoulou A, Yiallouros PK et al. Association of vitamin D with adiposity measures and other determinants in a crosssectional study of Cypriot adolescents. Public Health Nutr 2014; 17: 1-10.

32. Vaidya A, Williams JS. The relationship between vitamin D and the renin-angiotensin system in the pathophysiology of hypertension, kidney disease, and diabetes. Metabolism 2012; 61 (4): 450-458.

33. Sypniewska G, Pollak J, Strozecki P et al. 25-Hydroxyvitamin D, Biomarkers of Endothelial Dysfunction and Subclinical Organ Damage in Adults With Hypertension. Am J Hypertens 2014; 27 (1): 114-121.

34. Forouhi NG, Luan J, Cooper A, Boucher BJ, Wareham NJ. Baseline serum 25-hydroxy vitamin D is predictive of future glycemic status and insulin resistance - The Medical Research Council Ely Prospective Study 1990-2000. Diabetes 2008; 57 (10): 2619-2625.

35. Tamez H, Kalim S, Thadhani RI. Does vitamin D modulate blood pressure? Curr Opin Nephrol Hypertens 2013; 22 (2): 204-209.

36. Witham MD, Ireland S, Houston JG et al. Vitamin D Therapy to Reduce Blood Pressure and Left Ventricular Hypertrophy in Resistant Hypertension Randomized, Controlled Trial. Hypertension 2014; 63 (4): $706-712$.
37. Larsen T, Mose FH, Bech JN, Hansen AB, Pedersen EB. Effect of Cholecalciferol Supplementation During Winter Months in Patients With Hypertension: A Randomized, Placebo-Controlled Trial. Am J Hypertens 2012; 25 (11): 1215-1222.

38. Pourshahidi LK. Vitamin D and obesity: current perspectives and future directions. Proc Nutr Soc 2014: in press.

39. Vimaleswaran KS, Berry DJ, Lu C et al. Causal Relationship between Obesity and Vitamin D Status: Bi-Directional Mendelian Randomization Analysis of Multiple Cohorts. Plos Med 2013; 10 (2): e1001383.

40. Brot C, Jorgensen NR, Sorensen OH. The influence of smoking on vitamin D status and calcium metabolism. Eur J Clin Nutr 1999; 53 (12): 920-926.

41. Shinkov A, Borissova AM, Dakovska L, Vlahov J, Kassabova L, Svinarov D. Winter 25-hydroxyvitamin D levels in young urban adults are affected by smoking, body mass index and educational level. Eur J Clin Nutr 2014: in press.

42. Soldin OP, Makambi KH, Soldin SJ, O'Mara DM. Steroid hormone levels associated with passive and active smoking. Steroids 2011; 76 (7): 653-659.

Received August 9, 2016 Accepted September 7, 2016. 